\title{
The Effects of Galanin on Growth Hormone Secretion in Children of Normal and Short Stature $^{1}$
}

\author{
SANDRO LOCHE, SILVANO G. CELLA, ROSA PUGGIONI, LILIANA STABILINI, \\ CARLO PINTOR, AND EUGENIO E. MÜLLER
}

Department of Pediatrics, Chair of Pediatric Endocrinology, University of Cagliari, Cagliari; and Department of Pharmacology, University of Milan, Milan (S.G.C., E.E.M.J, Italy

\begin{abstract}
We have evaluated the effect of galanin (Gal), a newly identified hypothalamic peptide, on growth hormone (GH) secretion in 10 children with normal stature (NS), nine with constitutional growth delay (CGD), and five with isolated GH deficiency (IGHD). Gal was infused intravenously at a rate of 8 or $15 \mu \mathrm{g} / \mathrm{kg} / \mathrm{h}$. All children also underwent an acute oral clonidine test $\left(0.15 \mathrm{mg} / \mathrm{m}^{2}\right)$. In CGD children the mean plasma $\mathrm{GH}$ peak after $8 \mu \mathrm{g} / \mathrm{kg} / \mathrm{h}$ of Gal infusion $(13.3 \pm 1.7 \mathrm{ng} / \mathrm{mL}$; mean $\pm \mathrm{SEM})$ was higher $(p<0.02)$ than in NS children $(8.5 \pm 0.8 \mathrm{ng} / \mathrm{mL})$. When the dose of Gal was increased to $15 \mu \mathrm{g} / \mathrm{kg} / \mathrm{h}$ the mean plasma GH peak in CGD children (18.5 $\pm 3.5 \mathrm{ng} /$ $\mathrm{mL})$ was still higher than in the NS group $(13.2 \pm 2.9 \mathrm{ng} /$ $\mathrm{mL}$ ), although not significantly so. In IGHD children the mean plasma GH peak elicited by 8 or $15 \mu \mathrm{g} / \mathrm{kg} / \mathrm{h}$ of $\mathrm{Gal}$ $(3.8 \pm 0.7$ and $3.9 \pm 0.5 \mathrm{ng} / \mathrm{mL}$, respectively) was lower than that obtained in either CGD $(p<0.0002)$ or NS children $(p<0.001)$. In NS children the mean plasma GH peak after acute clonidine administration $(22.3 \pm 3.0 \mathrm{ng} /$ $\mathrm{mL}$ ) was higher than that observed after either dose of Gal used $(p<0.001$ and $p<0.05$ with 8 and $15 \mu \mathrm{g} / \mathrm{kg} / \mathrm{h}$, respectively). In CGD or IGHD children mean plasma GH peak after acute clonidine $(14.8 \pm 2.6$ and $4.1 \pm 1.2 \mathrm{ng} /$ $\mathrm{mL}$, respectively) was not significantly different from that observed after either dose of Gal. No correlation was found between peak plasma $\mathrm{GH}$ responses to clonidine and to Gal infusion at either dose used. Gal infusion did not cause any significant change in LH, FSH, prolactin, and TSH plasma levels. We conclude that $\mathrm{Gal}$ stimulates $\mathrm{GH}$ secretion in CGD as well in NS children but not in children with isolated GH deficiency. Gal, at least under our experimental conditions, does not seem to be of help in the differential diagnosis of children with short stature. (Pediatr Res 26:316-319, 1989)
\end{abstract}

\section{Abbreviations}

CGD, constitutional growth delay

Gal, galanin

GH, growth hormone

GHRH, GH-releasing hormone

IGHD, isolated GH deficiency

NS, normal stature

Received November 17, 1988; accepted May 15, 1989.

Correspondence Prof. Carlo Pintor, Cattedra di Endocrinologia Pediatrica, Ospedale Microcitemico, Via Jenner, 09100 Cagliari, Italy.

${ }^{1}$ Presented in part at the Eighth International Congress of Endocrinology, Kyoto, Japan, July 17-23, 1988 .
Gal is a 29-amino acid peptide which was first isolated from porcine intestine (1) and then found in high concentrations in the mammalian CNS $(2,3)$. Gal administration stimulates $\mathrm{GH}$ secretion in both animals (4-6) and adult men (7). Gal infusion also enhances the $\mathrm{GH}$ response to a single injection of GHRH (8) and abolishes the inhibitory effect of cholinergic antagonist drugs on the GHRH-induced GH secretion in normal men (9).

All these findings are suggestive for a role of Gal in the control of GH secretion. They prompted us to study whether Gal also stimulates GH secretion in children of NS, in children with CGD and in children with IGHD, and to investigate whether Gal would be of any potential use in the differential diagnosis of short children.

\section{MATERIALS AND METHODS}

Ten NS children (seven boys and three girls), nine children with CGD (seven boys and two girls), and five children with IGHD (three boys and two girls) were studied. The study was approved by the ad hoc Ethical Committee of the Department of Pediatrics of the University of Cagliari, and informed consent was obtained from the children's parents before the study.

The diagnosis of IGHD was made by classical criteria, i.e. plasma $\mathrm{GH}$ levels $<10 \mathrm{ng} / \mathrm{mL}$ after two pharmacologic tests (clonidine and insulin hypoglycemia), subnormal growth rates and delayed bone age. In none of the children with IGHD studied was any apparent cause of their defect found, and therefore it was regarded as idiopathic. The diagnosis of CGD was made in children with a stature below the 3rd percentile for age (Tanner growth charts), delayed bone age, a normal $\mathrm{GH}$ response $(>10$ $\mathrm{ng} / \mathrm{mL}$ ) to acute oral clonidine and/or insulin hypoglycemia, and a history of delayed growth and adolescence in other family members. None of the CGD children had signs of malnutrition, dysmorphic syndromes, or psychosocial disturbances. All NS children had a stature above the 3rd percentile and a normal growth rate for age. They referred to our department for minor nonendocrine diseases (upper tract respiratory infections) or for short stature (ultimately found to be normal) and were asked to participate in the study. Patients 1 and 5 had a family history of delayed growth and sexual maturation. The main clinical and laboratory characteristics of all children studied are summarized in Table 1. Gal (synthetic porcine, Inalco, Milan, Italy) prepared for human use and dissolved in $250 \mathrm{~mL}$ of saline was infused intravenous at a rate of 8 and/or $15 \mu \mathrm{g} / \mathrm{kg} / \mathrm{h}$ for $1 \mathrm{~h}$ through an indwelling catheter. In particular, children $2,5,8,12,13$, and 17 of Table 1 were tested only once with the lower dose of Gal, whereas all the remaining children received both doses of the peptide in a random order. Gal infusion was started after $60 \mathrm{~min}$ of saline infusion, which was also continued for $2 \mathrm{~h}$ after $\mathrm{Gal}$. All studies were started between 0800 and 0900 after the children 
fasted overnight. In IGHD children the experiments were performed 2 to $3 \mathrm{wk}$ after discontinuation of $\mathrm{GH}$ therapy.

All children also underwent an acute oral clonidine test $(0.15$ $\mathrm{mg} / \mathrm{m}^{2}$ ) as previously described (10). In addition, children with IGHD were also tested with GHRH (hpGRF 1-40, Bachem, Bubendorf, Switzerland) at the dose of $1.0 \mu \mathrm{g} / \mathrm{kg}$ intravenous (11).

GH was measured by double antibody RIA using reagents provided by Radim (Rome, Italy). The sensitivity of the $\mathrm{GH}$ assay was $1.0 \mathrm{ng} / \mathrm{mL}$ with an intra- and interassay coefficient of variation of 2.8 and $5.1 \%$, respectively. $\mathrm{LH}, \mathrm{FSH}, \mathrm{TSH}$, and prolactin levels were also measured by RIA in each sample as previously described (11). Baseline IGF-I levels were measured in all children using reagents provided by the Nichols Institute Diagnostic (San Juan Capistrano, CA). Details on the IGF-I assay in our laboratory have been reported elsewhere (12).

The statistical significance of the differences was evaluated by means of paired or unpaired $t$-test preceded by ANOVA. A $p<$ 0.05 (two-tailed) was considered to indicate a significant difference. Correlations were calculated by regression analysis. All values are given as the mean \pm SEM.

\section{RESULTS}

Gal administration was well tolerated and did not induce noticeable side effects in any of the children studied. Gal stimulated GH secretion in both NS and CGD children at either dose used, but only to a small degree in the children with IGHD (Fig.
1). In children with CGD the mean plasma GH peak elicited by $8 \mu \mathrm{g} / \mathrm{kg} / \mathrm{h}$ of Gal infusion $(13.3 \pm 1.7 \mathrm{ng} / \mathrm{mL})$ was significantly higher $(p<0.02)$ than in NS children $(8.5 \pm 0.8 \mathrm{ng} / \mathrm{mL})$ (Table 2). When the dose of Gal was increased to $15 \mu \mathrm{g} / \mathrm{kg} / \mathrm{h}$ the mean plasma $\mathrm{GH}$ peak in CGD children $(18.5 \pm 3.5 \mathrm{ng} / \mathrm{mL})$ was still higher than in the NS group $(13.2 \pm 2.9 \mathrm{ng} / \mathrm{mL})$, although the difference did not reach statistical significance (Table 2). When all $\mathrm{GH}$ peaks obtained with the two doses of Gal were combined, their mean was significantly higher $(p<0.02)$ in the CGD $(15.4$ $\pm 1.9 \mathrm{ng} / \mathrm{mL})$ than in the NS children $(10.4 \pm 1.4 \mathrm{ng} / \mathrm{mL})$.

In IGHD children the mean plasma GH peak elicited by 8 or $15 \mu \mathrm{g} / \mathrm{kg} / \mathrm{h}$ of $\mathrm{Gal}(3.8 \pm 0.7$ and $3.9 \pm 0.5 \mathrm{ng} / \mathrm{mL}$, respectively) was significantly lower than that obtained in both CGD $(p<$ $0.0002)$ and NS children $(p<0.001)$ (Table 2).

In NS children the mean plasma $\mathrm{GH}$ peak after acute clonidine administration $(22.6 \pm 3.0 \mathrm{ng} / \mathrm{mL})$ was significantly higher than that observed after either dose of Gal used $(p<0.001$ and $<0.05$ with 8 and $15 \mu \mathrm{g} / \mathrm{kg} / \mathrm{h}$, respectively) (Table 2). In CGD children the mean plasma $\mathrm{GH}$ peak after acute clonidine $(14.8 \pm 2.6 \mathrm{ng} /$ $\mathrm{mL}$ ) was not significantly different from that observed after either dose of Gal (Table 2). In IGHD patients the mean plasma GH peak after acute clonidine $(4.1 \pm 1.2 \mathrm{ng} / \mathrm{mL})$ was not significantly different from that observed after 8 or $15 \mu \mathrm{g} / \mathrm{kg} / \mathrm{h}$ of Gal infusion. In none of the IGHD children were peak GH levels influenced by increasing the dose of Gal. No correlation was found between the plasma $\mathrm{GH}$ peak in responses to clonidine and to Gal infusion at either dose used, or between the age of the children and the $\mathrm{GH}$ responsiveness to Gal. In eight of 13 children peak $\mathrm{GH}$ levels

Table 1. Main clinical and laboratory characteristics of children studied

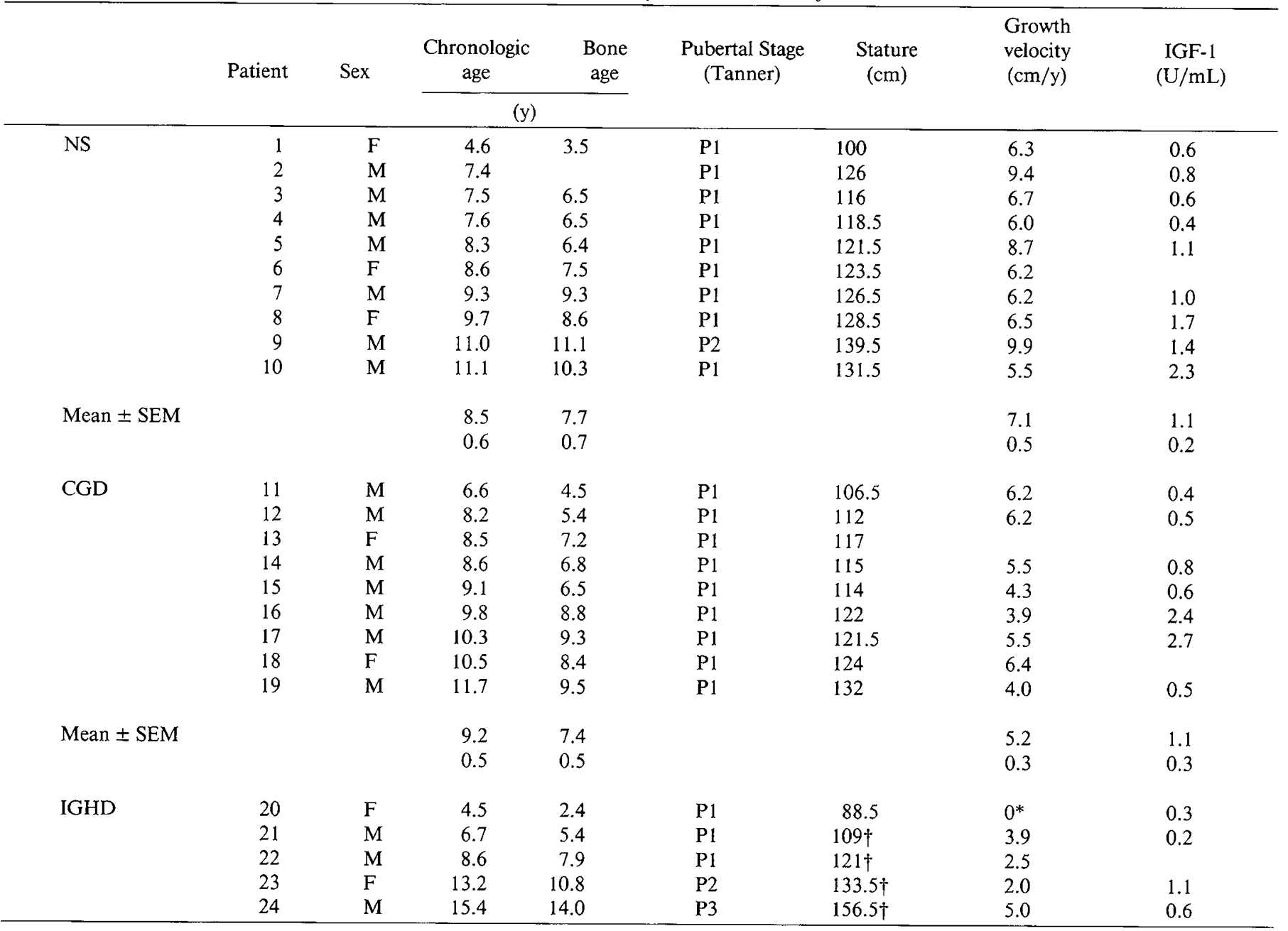

* Calculated over 3 mo.

† On GH replacement therapy. 

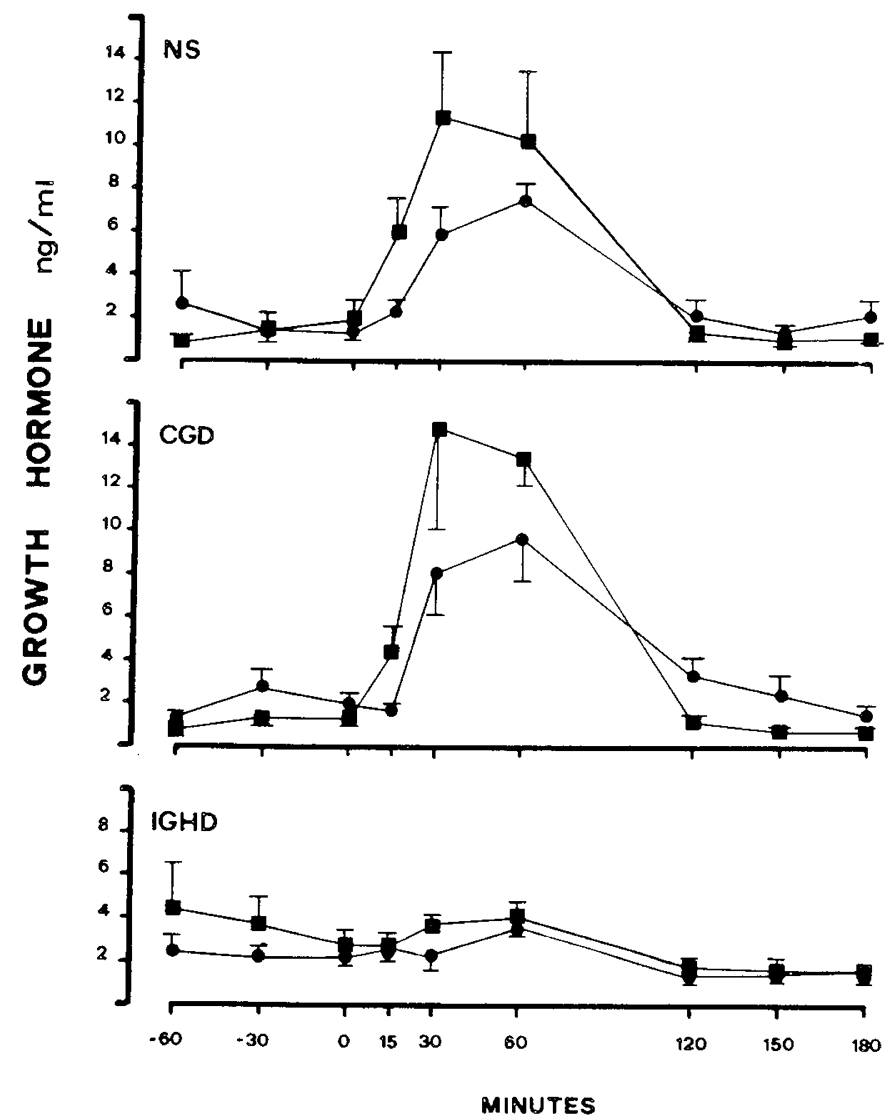

Fig. 1. Mean \pm SEM of the plasma $\mathrm{GH}$ response to the infusion of 8 (†) or $15(\mathbf{D}) \mu \mathrm{g} / \mathrm{kg} / \mathrm{h}$ intravenous of Gal in children of NS, children with CGD, and with IGHD.

elicited by the higher dose of Gal were higher than those observed after the lower dose (Table 2).

Two of the children with IGHD (nos. 23 and 24, Table 1) had a subnormal $(<10 \mathrm{ng} / \mathrm{mL}) \mathrm{GH}$ increase after GHRH $(2.4$ and $6.3 \mathrm{ng} / \mathrm{mL}$, respectively), whereas the remaining three patients showed a $\mathrm{GH}$ increase after the releasing hormone $>10 \mathrm{ng} / \mathrm{mL}$ $(17.2,19.1$, and $10.8 \mathrm{ng} / \mathrm{mL}$, respectively, in nos. 20,21 , and 22).

In children with IGHD (nos. 21-24) growth velocity during the first year of $\mathrm{GH}$ treatment $\left(12 \mathrm{U} / \mathrm{m}^{2}\right.$ three times weekly) was $8.5,9.0,9.0$, and $10.0 \mathrm{~cm}$, respectively. In patient 20 the growth velocity during the first 6 mo of treatment was $8.0 \mathrm{~cm} / \mathrm{y}$.

Gal infusion did not cause any significant change in $\mathrm{LH}, \mathrm{FSH}$, $\mathrm{TSH}$, and prolactin plasma levels at either dose used (data not shown).

\section{DISCUSSION}

$\mathrm{GH}$ secretion is regulated by the combined action of GHRH and somatostatin, which respectively stimulate and inhibit its release from the pituitary. The release of these two hypothalamic peptides is, in turn, regulated by a host of brain neurotransmitters and neuropeptides (13). The finding of high Gal concentrations in the hypothalamus and median eminence $(2,3)$ raised the hypothesis of its possible role in the control of anterior pituitary hormone secretion, and in fact $\mathrm{Gal}$ has been shown to stimulate GH release when injected systemically (6) or intracerebroventricularly (4) in the rat and intravenously in normal adult men (79 ). It has also been shown to stimulate prolactin secretion in the rat (14), a finding which was not replicated in normal men (7) nor in the children of this study.

Previous animal studies have shown that the hypothalamus is the site of action of Gal to release GH (5), and that this effect is
Table 2. Peak $G H$ responses $(n g / m L)$ to clonidine and Gal in all children studied

\begin{tabular}{|c|c|c|c|c|}
\hline & \multirow[b]{2}{*}{ Case } & \multirow[b]{2}{*}{ Clonidine } & \multicolumn{2}{|c|}{ Gal } \\
\hline & & & $(8 \mu \mathrm{g} / \mathrm{kg} / \mathrm{h})$ & $(15 \mu \mathrm{g} / \mathrm{kg} / \mathrm{h})$ \\
\hline \multirow[t]{10}{*}{ NS } & 1 & 22.8 & 5.2 & 3.7 \\
\hline & 2 & 17.1 & 7.6 & \\
\hline & 3 & 30.0 & 7.7 & 12.1 \\
\hline & 4 & 27.2 & 6.0 & 8.2 \\
\hline & 5 & 35.4 & 10.6 & \\
\hline & 6 & 6.2 & 13.1 & 10.3 \\
\hline & 7 & 35.0 & 7.5 & 16.7 \\
\hline & 8 & 11.9 & 7.7 & \\
\hline & 9 & 14.9 & 13.2 & 30.2 \\
\hline & 10 & 26.0 & 6.2 & 11.3 \\
\hline \multirow[t]{2}{*}{ Mean \pm SEM } & & 22.6 & 8.5 & 13.2 \\
\hline & & 3.0 & 0.8 & 2.9 \\
\hline \multirow[t]{9}{*}{ CGD } & 11 & 21.4 & 12.5 & 10.8 \\
\hline & 12 & 25.4 & 9.6 & \\
\hline & 13 & $5.1^{*}$ & 16.9 & \\
\hline & 14 & $4.7^{*}$ & 7.6 & 14.6 \\
\hline & 15 & 12.9 & 16.9 & 37.0 \\
\hline & 16 & 12.3 & 15.3 & 19.8 \\
\hline & 17 & 26.6 & 4.6 & \\
\hline & 18 & $6.4^{*}$ & 23.0 & 15.5 \\
\hline & 19 & 18.3 & 13.8 & 13.7 \\
\hline \multirow[t]{2}{*}{ Mean \pm SEM } & & 14.8 & 13.3 & 18.5 \\
\hline & & 2.6 & 1.7 & 3.5 \\
\hline \multirow[t]{5}{*}{ IGHD } & 20 & 3.7 & 5.9 & 5.6 \\
\hline & 21 & 9.4 & 2.2 & 2.5 \\
\hline & 22 & 2.5 & 2.6 & 3.1 \\
\hline & 23 & 2.4 & 3.4 & 5.0 \\
\hline & 24 & 2.6 & 5.2 & 3.3 \\
\hline \multirow[t]{2}{*}{ Mean \pm SEM } & & 4.1 & 3.8 & 3.9 \\
\hline & & 1.2 & 0.7 & 0.5 \\
\hline
\end{tabular}

${ }^{*} \mathrm{GH}$ response $>10 \mathrm{ng} / \mathrm{mL}$ during insulin hypoglycemia.

medicated by GHRH (4). In fact, Gal was unable to stimulate GH release from dispersed, cultured rat anterior pituitary cells (4). Two recent studies in men, however, have suggested that Gal may stimulate $\mathrm{GH}$ release via inhibition of somatostatin $(8,9)$.

Whichever its mechanism of action, we have shown here that Gal stimulated GH release consistently in both normal and CGD children, but not in children with IGHD. The fact that Gal stimulated GH secretion to a greater extent in CGD than in NS children is intriguing. Theoretically, it might indicate that CGD children have an increased endogenous somatostatin tone that would be counteracted by Gal $(8,9)$.

We do not know whether the highest dose of Gal we have used in this study produced the maximal GH response. Nonetheless, we can conclude that Gal stimulates GH secretion in CGD as well as in NS children but not in children with IGHD. Gal, at least under our experimental conditions, does not seem to be of help in unraveling peculiar neurochemical alterations in individual children with CGD. It cannot be excluded, however, that it may be useful to probe endogenous somatostatin function in the hypothalamus $(8,9)$ and its possible clinical implications in growth disorders.

\section{REFERENCES}

1. Tatemoto K, Rökaeus $\AA$, Jöruvall H, McDonald TJ, Mutt V 1983 Galanina novel biologically active peptide from porcine intestine. FEBS Lett 164:124-128

2. Rökaeus $\AA$, Melander T, Hökfelt T, Lundberg JM, Tatemoto K, Carlquist M, 
Mutt V 1984 A galanin-like peptide in the central nervous system and intestine of the rat. Neurosci Lett 47:161-166

3. Skofitsch G, Jacobowitz DM 1985 Immunohistochemical mapping of galaninlike neuron in the rat central nervous system. Peptides 6:509-546

4. Murakami Y, Kato Y, Koshiyama H, Inoue T, Yanaihara N, Imura H 1987 Galanin stimulates growth hormone $(\mathrm{GH})$ secretion via $\mathrm{GH}$-releasing factor (GRF) in conscious rats. Eur J Pharmacol 136:415-418

5. Ottlecz A, Samson WK, McCann SM 1986 Galanin: evidence for a hypothalamic site of action to release growth hormone. Peptides 7:51-53

6. Cella SG, Locatelli V, De Gennaro V, Bondiolotti GP, Pintor C, Loche S, Provezza M, Müller EE 1988 Epinephrine mediates the growth hormonereleasing effect of galanin in infant rats. Endocrinology 122:855-859

7. Bauer FE, Ginsberg L, Venetikou M, MacKay DJ, Burrin JM, Bloom SR 1986 Growth hormone release in man induced by galanin, a new hypothalamic peptide. Lancet 2:192-194

8. Davis TME, Burrin JM, Bloom SR 1987 Growth hormone $(\mathrm{GH})$ release in response to GH-releasing hormone in man is 3 -fold enhanced by galanin. $\mathbf{J}$ Clin Endocrinol Metab 65:1248-1252

9. Chatterjee VKK, Ball JA, Proby C, Burrin JM, Bloom SR 1987 Galanin abolishes the inhibitory effect of cholinergic blockade on growth hormonereleasing hormone-induced secretion of growth hormone in man. J Endocrinol 116:R1-R2

10. Pintor C, Loche S, Corda R, Cella SG, Puggioni R, Locatelli V, Müller EE 1987 Clonidine treatment for short stature. Lancet 1:1226-1230

11. Pintor C, Fanni V, Loche S, Locatelli V, Villa F, Cella SG, Minuto F, Corda R, Müller EE 1983 Synthetic hpGRF 1-40 stimulates growth hormone and inhibits prolactin secretion in normal children and in children with isolated growth hormone deficiency. Peptides 4:929-934

12. Loche S, Cappa M, Borrelli P, Faedda A, Crino A, Cella SG, Corda R, Müller EE, Pintor C 1987 Reduced growth hormone response to growth hormone releasing hormone in children with simple obesity: Evidence for somatomedin C mediated inhibition. Clin Endocrinol 27:145-153

13. Müller EE 1986 Neural control of somatotropic function. Physiol Rev 67:1962-2053

14. Koshiyama $\mathrm{H}$, Kato $\mathrm{Y}$, Inoue $\mathrm{T}$, Murakami $\mathrm{Y}$, Ishikawa $\mathrm{Y}$, Yanaihara N, Himura $\mathrm{H} 1987$ Central galanin stimulates pituitary prolactin secretion in rats: possible involvement of hypothalamic vasoactive intestinal polypeptide. Neurosci Lett 75:49-54 